\title{
Jowita Grzelak
}

University of Warsaw

e-mail: jgrzelak@wz.uw.edu.pl

ORCID: 0000-0002-6772-1019

\section{DETERMINANTS OF THE BANKRUPTCY RISK OF COMMERCIAL BANKS IN CENTRAL AND EASTERN EUROPE}

\section{DETERMINANTY RYZYKA UPADŁOŚCI BANKÓW KOMERCYJNYCH EUROPY ŚRODKOWO-WSCHODNIEJ}

DOI: $10.15611 /$ pn.2020.1.05

JEL Classification: G21, G33

Summary: The collapse of Lehman Brothers, known as the beginning of the global financial crisis, showed how important risk management is in a bank. The aim of the article is to analyze bankruptcy risk factors of commercial banks from CEE. The hypothesis assumes that bank's features: profitability, asset quality, size, credit risk, structure of assets, the direction of the core business and sources of financing, have a statistically significant impact on the bankruptcy. To verify the hypothesis, an econometric model was built which examined the determinants in three areas: comprehensively, dividing into large and small banks and by the EU membership criterion. The analysis showed that the risk of bankruptcy is affected by: profitability, asset quality, bank size, asset structure and core business direction; the determinants of bankruptcy vary depending on the size of the bank; the country's membership in the EU does not affect the type of determinants but only the strength of their influence.

Keywords: bank, panel data, default risk.

Streszczenie: Upadek Lehman Brothers, znany jako początek światowego kryzysu finansowego, pokazał, jak ważne jest zarządzanie ryzykiem w banku. Celem artykułu jest analiza determinant ryzyka upadłości banków komercyjnych z krajów EŚW. Postawiona hipoteza zakłada, że cechy banku: rentowność, jakość aktywów, wielkość, ryzyko kredytowe, struktura aktywów, kierunek działalności podstawowej i źródło finansowania, mają statystycznie istotny wpływ na ryzyko bankructwa. Aby zbadać hipotezę, zbudowano model ekonometryczny, który pozwolił na analizę determinant w trzech ujęciach: kompleksowo dla próby badawczej, w podziale na banki duże i małe oraz $\mathrm{z}$ wykorzystaniem kryterium przynależności do UE. Badanie wykazało, że na ryzyko upadłości istotnie wpływają: rentowność, jakość aktywów, wielkość banku, struktura aktywów oraz kierunek działalności podstawowej; determinanty upadłości różnią się w zależności od wielkości banku; przynależność kraju do UE nie wpływa na rodzaj determinant, lecz na siłę ich oddziaływania.

Słowa kluczowe: bank, dane panelowe, ryzyko upadłości. 


\section{Introduction}

While for the individual, the effects of risk are severe for him/her and a few people from his/her environment, the matter is much more complicated if one delves into the risk and its consequences when it comes to commercial banks. The need to regulate banking activity was emphasized in the classical economics by Ricardo, who claimed that banks are institutions that use other people's money [McDonald, Keasey 2002, p. 5]. The answer to the need to regulate banks' operations is the Basel Committee, which is a board of experts in finance and banking. Its recommendations are not strictly binding law but many countries decide to apply them [Żółtkowski 2007, pp. 29-30]. Nowadays, the role of preventive behavior and monitoring the financial condition is emphasized and is the subject of the Basel regulations [Nieborak 2001, pp. 51-66].

The aim of the article is to analyze the determinants of the bankruptcy risk of commercial banks from CEE countries. The article hypothesizes that all independent variables selected for analysis, representing such areas of the bank as: profitability, asset quality, bank size, credit risk, asset structure, core business direction and source of financing, significantly influence the capital adequacy ratio, which represents the bankruptcy risk. The verification of the hypothesis was made in three perspectives: comprehensively for the whole research group, divided into large and small banks and for banks from countries belonging to and not belonging to the European Union.

\section{Literature review}

In the literature there can be found specially constructed models for predicting the bankruptcy of banks [Kasiewicz, Rogowski 2006, p. 6]. The review of the literature was aimed at selecting variables used by researchers to analyze a bank's bankruptcy risk, which are presented in Table 1.

The problem of searching for determinants of bankruptcy arises in many articles, where this risk was represented by the capital adequacy ratio, which, according to authors, has properties to assess the risk of default. This coefficient was used by Estrella, Parka and Peristiani, who showed that two simple ratios (financial leverage and bank capital to gross income) can predict just as well as the complex indicators, bankruptcy in a 1 or 2-year horizon, although risk-weighted ratios perform default better in the case of longer horizons [Estrella, Parka, Peristiani 2000, pp. 33-52]. Cox and Wang's model that best predicted bankruptcy included: mortgage loans, growth rates, share balances, size of the bank's portfolio, loan losses, non-performing loans, net charges and property taken over. It was considered that the cause of bankruptcy is a higher proportion of the value of bad mortgage loans and non-performing debts [Cox, Wang 2014]. Cleary and Hebb analyzed the default of banks by applying discriminatory analysis which showed that the two most important variables were the capital of banks and the quality of loans [Cleary, Hebb 2016]. Zaghdoudi developed 
a model of predicting banks' collapse which proved that the ability to repay debt, operations ratio, profitability per employee and leverage ratio have a negative impact on the default risk [Zaghdoudi 2013, pp. 537-543].

Researchers used credit ratings to analyze bankruptcy risk for banks, explaining that these scores contain information and assessments of many risks associated with banking operations. Hassan and Barrell showed that a small number of ratios (size, liquidity, efficiency) are strongly related to banks'credit ratings. Moreover, these ratios are able to better explain the ratings of the best-rated banks in the future and for the lowest-rated banks past ratings [Hassan, Barell 2013]. Hau, Langfield and MarquesIbanez studied the quality of credit ratings which showed banks' creditworthiness. The results pointed out that large banks receive more positive scores, especially from agencies for which they provide securitization [Hau, Langfield, MarquesIbanes 2012]. Shen, Huang and Hasan studied an information asymmetry hypothesis to examine why the credit ratings vary from country to country. They proved that indicators that affect the rating of banks have a significant impact on information asymmetry [Shen, Huang, Hasan 2012, pp. 171-193]. Belotti, Matousek and Stewart stated that banks' ratings reflect their financial condition, analysis time and country of origin. They showed that banks with bigger capital, larger assets and higher ROA are given higher ratings [Belotti, Matousek, Stewart 2011, pp. 4206-4214]. Chodnicka-Jaworska studied the impact of financial indicators on credit ratings of banks from euro area countries, emphasizing the importance of scores given by rating agencies as a source of information for assessing the risk of bankruptcy. The results showed that financial indicators (CAMEL) have a statistically significant impact on the credit ratings of banks, however, this impact does not occur with all indicators and not all indicators affect the credit rating with the same strength. This could result from the fact that the analyzed rating agencies do not use the same indicators for assessments - thus they verify the influence of various determinants [Chodnicka-Jaworska 2016, pp. 27-37].

Many studies use the derivatives that banks issue to analyze bankruptcy risk. CDSs may be related to the bankruptcy when the bank loses its solvency. Understanding insolvency as a bankruptcy, spreads on CDS may represent default. Ötker-Robe and Podpiera showed the variables that drive CDS in the initial phase of the crisis in European financial institutions (LCFI). LCFIs' business models, their earning potential and economic uncertainty belong to factors influencing credit risk [Ötker-Robe, Podpiera 2010, pp. 1-31]. Chodnicka-Jaworska and Jaworski focused on the analysis of factors affecting CDS spreads of banks. The conclusion is that the CDS spreads are closely related to business models, earnings potential, and macroeconomic conditions [Chodnicka-Jaworska, Jaworski 2017, pp. 51-63]. 
Table 1. Variables used to predict the bankruptcy of banks

\begin{tabular}{|c|c|c|}
\hline No. & Variables & Literature source \\
\hline 1 & 2 & 3 \\
\hline 1. & $\begin{array}{l}\text { Solvency ratio (core capital/risk weighted assets), leverage ratio (core } \\
\text { capital/tangible assets), revenue ratio (share capital/interest and non- } \\
\text { interest income before deducting expenses) }\end{array}$ & $\begin{array}{l}\text { [Estrella, Park, } \\
\text { Peristiani } \\
\text { 2000] }\end{array}$ \\
\hline 2. & $\begin{array}{l}\text { ROA, ROE, tier 1, tier 2, z-score, financial leverage, short-term loans } \\
\text { to total liabilities, deposits, liquid assets to total assets, long-term Fitch } \\
\text { country rating, net interest income on interest-bearing assets, net trading } \\
\text { income to revenues total, specific provisions for total loans, operating } \\
\text { costs for operating income, share of non-performing loans in total loans }\end{array}$ & $\begin{array}{l}{[\text { Ötker-Robe, }} \\
\text { Podpiera 2010] }\end{array}$ \\
\hline 3. & $\begin{array}{l}\text { Average value of indicators from the last } 3 \text { years: liabilities subordinated } \\
\text { to liquid assets, logarithmized assets, equity to total assets, assets to } \\
\text { the number of loan agreements, gross loan growth rate, difference of } \\
\text { total long-term financing and equity to total assets, loan provisions to } \\
\text { gross loans, interest liabilities to interest assets, loans to deposits, net } \\
\text { interest income to interest assets, net loans to total assets, difference in } \\
\text { net interest income and provisions to interest assets, non-interest costs to } \\
\text { total assets, costs to income }\end{array}$ & $\begin{array}{l}{[\text { Hassan, }} \\
\text { Barrell } \\
2013]\end{array}$ \\
\hline 4. & $\begin{array}{l}\text { Share of mortgage loans in total assets, increase in the sum of loans } \\
\text { and leasing granted, bank size, return on assets ratio, share of non- } \\
\text { performing loans in total loans }\end{array}$ & $\begin{array}{l}{[\text { Cox }} \\
\text { Wang } \\
2014]\end{array}$ \\
\hline 5. & $\begin{array}{l}\text { HHI index, crisis, short-term loans to assets, the rate of increase in loans, } \\
\text { share of derivatives in assets, rate of return on assets, leverage }\end{array}$ & $\begin{array}{l}\text { [Hau, Langfield, } \\
\text { Marques-Ibanez 2012] }\end{array}$ \\
\hline 6. & $\begin{array}{l}\text { Cash to total asset value, ROA, loans to total assets value, loan loss } \\
\text { provisions to the value of loans, equity to total assets }\end{array}$ & $\begin{array}{l}\text { [Cleary, Hebb } \\
\text { 2016] }\end{array}$ \\
\hline 7. & $\begin{array}{l}\text { Average value of indicators from the last } 3 \text { years: liquid assets to } \\
\text { deposits, aggregated total assets, capital adequacy ratio, net profit to } \\
\text { total assets, specific provisions to net interest income }\end{array}$ & $\begin{array}{l}{[\text { Shen, Huang, }} \\
\text { Hasan } \\
\text { 2012] }\end{array}$ \\
\hline 8. & $\begin{array}{l}\text { Average value of ratios from the last } 3 \text { years: liquid assets to deposits, } \\
\text { capital adequacy ratio, net profit to total assets, specific provisions to net } \\
\text { interest income, logarithmized total assets }\end{array}$ & $\begin{array}{l}\text { [Bellotti, Matousek, } \\
\text { Stewart } \\
\text { 2011] }\end{array}$ \\
\hline 9. & $\begin{array}{l}\text { Deposits to assets, deposits to liabilities, loans to deposits, loans to loans, } \\
\text { debt to assets, fees to assets, banking products to assets, bank charges } \\
\text { to net profit, number of banking products to the number of employees, } \\
\text { loans to assets, loans to liabilities, loans to working capital, banking } \\
\text { products to assets, loans to the sum of the value of capital and reserves, } \\
\text { loans to the total value of deposits and loans, loans from the central bank } \\
\text { to liabilities, working capital to liabilities, deposits to the M2 aggregate }\end{array}$ & [Zaghdoudi 2013] \\
\hline 10. & $\begin{array}{l}\text { Tier I ratio, financial leverage, z-score, target provisions ratio to total } \\
\text { assets, share of non-performing loans in total loans, effectiveness index } \\
\text { (operational expenses to total revenues), securities ratio to working } \\
\text { assets, the ratio of net result to working assets, ROE, ROA, operating } \\
\text { leverage, loan growth rate, deposit growth rate, loan to deposit ratio, } \\
\text { short-term loans to total liabilities, liquid assets to total assets }\end{array}$ & $\begin{array}{l}\text { [Chodnicka-Jaworska } \\
\text { 2016] }\end{array}$ \\
\hline
\end{tabular}




\begin{tabular}{|c|c|c|}
\hline 1 & 2 & 3 \\
\hline 11. & $\begin{array}{l}\text { Tier I ratio, Tier } 2 \text { ratio, leverage ratio, provision for loan losses to the } \\
\text { total value of loans granted, ratio of non-performing loans to the total } \\
\text { value of loans, ratio of provisions to credit losses to the total value of } \\
\text { loan, effectiveness ratio (operating expenses to total revenues), exchange } \\
\text { income, net interest income ratio, return on equity, return on assets, loan } \\
\text { to deposit ratio, short-term receivables to total liabilities, liquid assets } \\
\text { to total assets ratio, market price, financing costs ratio, GDP growth, } \\
\text { indices on stock exchange (S\&P } 500 \text { or Euro 50), rate of return on 10- } \\
\text { year treasury bonds, overnight deposit rate on the interbank market }\end{array}$ & $\begin{array}{l}\text { [Chodnicka-Jaworska, } \\
\text { Jaworski } \\
2017]\end{array}$ \\
\hline
\end{tabular}

Source: own study.

\section{Data description and research methodology}

The aim of the study is to detect factors that significantly affect the bankruptcy risk of all commercial banks in Central and Eastern Europe listed on the stock exchanges. For this purpose financial microeconomic data of banks from 13 countries were collected (Lithuania, Poland, the Czech Republic, Slovakia, Hungary, Romania, Bulgaria, Montenegro, Russia, Ukraine, Serbia, Macedonia, Bosnia and Herzegovina). The data came from the Thomson Reuters database. The analysis omitted some banks operating in the analyzed countries due to gaps in the data (unbalanced panel). The analysis covers a period of ten years from 2007 to 2017.

The main hypothesis in the study assumes that features that characterize a bank, such as profitability, asset quality, size, credit risk, structure of assets, the direction of the core business and sources of financing have a statistically significant impact on the bankruptcy risk, represented by the capital adequacy ratio. The verification of the hypothesis was made in three perspectives: comprehensively for the whole research group, dividing banks from countries belonging to and not belonging to the EU, and for large and small banks.

In order to estimate the model, parameters were estimated using the Classic Least Squares Method. Then a diagnostic test of the panel model was carried out in order to verify the Breusch-Pagan test. It served to assess the significance of the variance of the random component. The next step was to check the nature of the effects that would allow to choose one of the two models: Random or Fixed Effects. For this purpose, the Hausman test was carried out, which allowed to assess the conformity of the random effects estimator. In order to assess the significance of individual effects, the Wald test was performed to verify the hypothesis that the regression parameters for the variables used in the model are 0 .

The hypothetical form of the model used to study the determinants of bankruptcy risk of banks in CEE countries has the form:

$$
\begin{gathered}
C A R_{i t}=\beta_{0}+\beta_{1} \text { ROA }_{i t}+\beta_{2} N P L_{i t}+\beta_{3} \ln A_{i t}+\beta_{4} L L P_{i t}+\beta_{5} L t A_{i t}+ \\
\beta_{6} \text { loangrowth }_{i t}+\beta_{7} \text { depgrowth } \\
\text { deat } \\
+\varepsilon_{i t}+u_{i t,}
\end{gathered}
$$


where: $C A R_{i t}$ - capital adequacy ratio, $\beta_{0}$ - constant equation, $\mathrm{ROA}_{\mathrm{it}}-$ return on assets, $N P L_{i t}$ - ratio of non-performing loans, $\ln A_{i t}$ - natural logarithm of total assets value, $L L P_{i t}$ - loan loss reserve ratio, $L t A_{i t}$ - share of loans in total assets, loangrowth ${ }_{i t}$ - growth rate of loans, depgrowth ${ }_{i t}$ - growth rate of deposits, $\varepsilon_{i t}$ - random error, $u_{i t}$ - vector of variables independent for the bank in time $t$.

The study assumed that the risk of bank's bankruptcy is represented by the risk of their insolvency [Hanweck 1977; Thompson 1991]. Therefore, the capital adequacy ratio, understood as the percentage share of total regulatory capital in risk weighted assets, was chosen as the dependent variable. This coefficient was calculated in accordance with the Thomson Reuters database methodology and was defined as the sum of Tier I, Tier II and Tier III capital in relation to risk-weighted assets. This ratio is a regulatory tool as it affects the supply of the bank loan and the structure of the bank's assets [Olszak 2006, pp. 111-142]. Capital adequacy is an important security indicator for depositors' funds, as it helps to reduce the crisis risk to which the bank is exposed [Al-Tamimi, Obeidat 2013, pp. 44-58].

The independent variables selected for the model were:

- ROA, return rate of assets. This indicator measures the effectiveness of managing available assets and reflects the effects of the bank's operating and financial activities [Al-Tamimi, Obeidat 2013, pp. 44-58]. The indicator used for the study was defined as the relation of net profit to the average state of the bank's assets.

- NPL, ratio of non-performing loans. This indicator is important in monitoring the activities of banks. Numerous studies proved that the asset quality understood in this way is an indicator of the bank's insolvency [Beck, Demirgüç-Kunt, Levine 2003, pp. 2-18; Barr, Siems 1994]. Banks whose NPL ratio remains at a high level are strongly at risk of bankruptcy [Messai, Jouini 2013, p. 852-860]. The indicator was constructed as a percentage share of non-performing loans in total gross loans.

- $\ln \mathrm{A}$, the natural logarithm of total assets. This ratio is often used as a relationship representing the size of the bank, which is a factor that affects the bank's capitals, ownership structure and access to equity. It was proved that larger banks manage risk better than smaller banks [Wong, Choi, Fong 2005, pp. 14-37]. This means that larger banks may maintain lower capital levels due to the fact that their strong market position will easily cover capital requirements from external sources.

- The loan loss provisions ratio (LLP). Its main task is to cover the expected credit losses of the bank. The analyses suggested that the loan loss provisions ratio is determined by the economic cycle, discretionary factors and unreasonable behavior of the bank's management [Caporale et al. 2017, pp. 239-243]. The indicator serves to analyze the quality of the loan portfolio in terms of its credit risk. It took the form of the ratio of provisions for loan losses to the total sum of loans. 
- The share of loans in the total bank's assets (LtA). This indicator was calculated using gross loans to the sum of assets. Loans are the main banking product offered and play an important role in developing economies. It has been proved that in the last 20 years in the CEE banks there were differences in the growth strategies of loans, which were caused by the phenomenon of income smoothing and procyclicality in banking operations [Skała 2015, pp. 61-169].

- Loan growth rate (loangrowth). This variable was calculated as the percentage of difference between the value of net loans in year $t$ and the value of loans in year $t-1$ to the value of loans granted in year $t-1$. A higher growth rate of loans implies lower standards of the loan portfolio and a higher percentage of potentially non-performing loans in the future [Yiqiang et al. 2018, pp. 1-20]. The lending activity grows at low interest rates and lowered loan requirements and cause an increase in banking risk, and is often caused by an aggressive strategy of market expansion [Keeton, William 1999, pp. 57-75].

- The growth rate of deposits (depgrowth). This variable is the percentage of the difference in the value of deposits in year $t$ and deposits in year $t-1$ to the value of deposits in year $t-1$. Considering that larger banks have better access to alternative sources of financing, they are less dependent on deposits and are less aggressive in acquiring them [Ibrahim, Rizvi 2018, pp. 31-47]. Researchers noted that banks with a higher rating position are characterized by a higher increase in deposits [Farooq, Zaheer 2015, pp. 101-124].

\section{Test results}

The results for the whole research group, small and large banks as well as banks belonging to and not belonging to EU countries are presented in Table 2.

For the entire sample, regression analysis using panel data with fixed effects showed that loan loss provisions ratio and deposit growth rate do not have a statistically significant impact on banks' capital adequacy ratio. At the same time, they adversely affect the dependent variable. A statistically significant impact was shown by: return on assets, non-performing loans ratio, the natural logarithm of assets, the share of loans in total assets and the rate of loan growth.

The division into large and small banks was made on the basis of the average value of the natural logarithm of assets maintained in the period 2007-2017. Banks with a lower average logarithm of assets than the average value for the entire sample $(\ln A=20.95)$ were assigned to the group of small banks. Other banks were considered as large.

Regression analysis using panel data with random effects showed that for large banks, asset return and natural logarithm of asset size do not have a statistically significant impact on the capital adequacy ratio. At the same time, the return on assets has a negative impact on the dependent variable, and the natural logarithm of assets has a positive effect. Among independent variables that statistically 
Table 2. Estimation results

\begin{tabular}{|c|c|c|c|c|c|c|c|c|c|c|}
\hline \multirow[t]{2}{*}{ Variables } & \multicolumn{2}{|c|}{$\begin{array}{l}\text { All CEE } \\
\text { countries }\end{array}$} & \multicolumn{2}{|c|}{ Small banks } & \multicolumn{2}{|c|}{ Big banks } & \multicolumn{2}{|c|}{$\begin{array}{c}\text { Banks from EU } \\
\text { countries }\end{array}$} & \multicolumn{2}{|c|}{$\begin{array}{c}\text { Banks } \\
\text { from non-EU } \\
\text { countries }\end{array}$} \\
\hline & coefficient & probability & coefficient & probability & coefficient & probability & coefficient & probability & coefficient & probability \\
\hline const & 74.1651 & 0.0000 & 115.348 & 0.0000 & 17.1836 & 0.0021 & 89.0587 & 0.0000 & 69.4864 & 0.0000 \\
\hline ROA & -53.6162 & 0.0000 & -94.8916 & 0.0000 & -3.4987 & 0.4202 & -86.9071 & 0.0000 & -48.4892 & 0.0000 \\
\hline NPL & 0.08344 & 0.000011 & 0.1288 & 0.0003 & 0.1160 & 0.0000 & 0.1925 & 0.0002 & 0.0617 & 0.0009 \\
\hline $\ln \mathrm{A}$ & -2.2016 & 0.0000 & -4.4338 & 0.0000 & 0.0047 & 0.9825 & -3.6980 & 0.0000 & -1.9751 & 0.0000 \\
\hline LLP & -1.0839 & 0.1263 & -0.9676 & 0.2560 & -4.4357 & 0.0001 & -8.7617 & 0.0005 & -1.5778 & 0.0187 \\
\hline LtA & -17.3712 & 0.0000 & -16.5795 & 0.0000 & -6.0105 & 0.0018 & 13.9989 & 0.0064 & -18.8471 & 0.0000 \\
\hline loangrowth & -0.000099 & 0.0374 & -0.0002 & 0.0014 & 0.0279 & 0.0000 & 0.0112 & 0.0414 & -0.0002 & 0.0003 \\
\hline depgrowth & -0.00126 & 0.2075 & 0.0061 & 0.0997 & -0.0414 & 0.0000 & -0.0165 & 0.0372 & 0.0076 & 0.0196 \\
\hline Hausman & & 0.0152 & & 0.0777 & & 0.8366 & & 0.3181 & & 0.0325 \\
\hline $\begin{array}{l}\text { Breusch- } \\
\text { Pagan }\end{array}$ & & 0.0000 & & 0.0000 & & 0.0000 & & 0.00000 & & 0.0000 \\
\hline Wald & & 0.0000 & & 0.0000 & & 0.0000 & & 0.0000 & & 0.0000 \\
\hline Type & & FE & & RE & & RE & & $\mathrm{RE}$ & & FE \\
\hline
\end{tabular}

Source: own study.

significantly affect the capital adequacy ratio the loan loss provisions, share of loans in assets and the growth rate of deposits have a negative impact on a dependent variable. However, the ratio of non-performing loans and the growth rate of loans have a positive impact.

In the case of small banks, only the loan loss provision ratio has no statistically significant effect on the capital adequacy ratio and the direction of its impact is negative. A statistically significant impact on the capital adequacy ratio was shown by: return on assets, non-performing loans, the natural logarithm of assets, ratio of loans in total assets, the growth rate of loans and the growth rate of deposits.

Regression analysis using panel data with random effects showed that in the case of banks operating in countries belonging to the European Union, all independent variables used for the study: return on assets, ratio of non-performing loans, natural logarithm of assets, loan loss provisions, loans in assets, the growth rate of loans and the deposit growth rate have a statistically significant impact on the capital adequacy. At the same time, the return on assets, the natural logarithm of the assets, the ratio of loan loss provisions and the rate of growth of deposits have a negative impact on the capital adequacy ratio. On the other hand, the ratio of non-performing loans, the ratio of loans in assets and the rate of growth of loans positively influence the dependent variable.

In the case of banks that operate in countries outside the European Union, all independent variables used for the study: return on assets ratio, share of nonperforming loans, natural logarithm of assets, loan loss provisions, loans in assets, 
loan growth rate and deposit growth have a statistically significant impact on the capital adequacy. As in the case of banks from EU countries, the return on assets, the natural logarithm of the assets, and the loan loss provisions ratio, negatively affect the capital adequacy ratio. In turn, the ratio of non-performing loans positively affects the dependent variable. The opposite direction of impact can be noted in the case of the growth rate of loans and the ratio of loans in assets that negatively affect the capital adequacy ratio, as well as the growth rate of deposits, which is characterized by a positive impact on the dependent variable.

The study showed that among selected variables, the determinants of the bankruptcy risk of commercial banks operating in CEE countries are areas such as: profitability, asset quality, bank size, asset structure and the direction of the bank's core business.

It was shown that the size of the bank influences the areas of its functioning that affect the risk of bankruptcy. In the case of small banks, these are: profitability, quality of held assets, bank size, structure of held assets, client's credit risk and source of business financing, whereas in the case of large banks: quality of assets maintained, credit risk, structure of held assets, direction of the core business and sources of business financing.

The location also determines areas of the bank's functioning that affect the risk of bankruptcy. The analyzed groups of banks belonging to or not belonging to countries from the EU are affected by all the analyzed areas of their operation: profitability, asset quality, size, credit risk, asset structure, direction of the core business and sources of financing, however the strength and direction of their impact varies between banks.

The main conclusion from the study is that commercial banks from CEE, wishing to improve their profitability, are willing to do so at the expense of their solvency by increasing the held assets, resulting in a deterioration in the quality of the loan portfolio.

\section{Conclusion}

The aim of the study was to find the determinants affecting the bankruptcy risk of banks in CEE. Default was represented by the Capital Adequacy Ratio. The author examined whether there is a statistically significant relationship, and if so, in which direction, between CAR and seven selected variables: assets profitability (profitability), non-performing loans (asset quality), the natural logarithm of assets (size), loan loss provisions (credit risk), share of loans in assets (asset structure), loan growth rate (the direction of core business) and deposit growth ratio (sources of financing).

Regression analysis showed that deposit growth rate and loan loss provisions do not have a statistically significant impact on the capital adequacy ratio of the analyzed sample. A statistically significant impact was demonstrated by the following 
variables: return on assets, non-performing loans, $\ln \mathrm{A}$ (bank size), ratio of loans in assets and the growth rate of loans. It is worth emphasizing that only the ratio of non-performing loans positively affects the capital adequacy ratio, and the remaining variables have a negative impact.

Due to the heterogeneity of the group of analyzed banks under many criteria, additional research was conducted to answer the question whether determinants affecting the risk of bankruptcy of banks in CEE differ due to the size of the bank and the country of operation.

The first division made it possible to distinguish two groups, i.e. small and large banks, whose bankruptcy determinants were separated by the analysis of panel data models, taking into account established individual effects. The inference made it possible to conclude that the size of banks influences the areas of their functioning that affect the risk of bankruptcy. In the case of small banks, these are: profitability, quality of held assets, bank size, structure of held assets, credit risk and source of business financing, and in the case of large banks: quality of assets maintained, credit risk, structure of held assets, direction of the core business and sources of business financing.

The study which focused on the analysis of banks operating in the European Union and not belonging to the Union, was aimed at checking whether the bank's location affects the bankruptcy risk. The study showed that in both cases the determinants are all the analyzed areas of the bank's activity: profitability, asset quality, bank size, credit risk, asset structure, direction of the core business and sources of financing. It is worth emphasizing, however, that all these determinants affect them with different strength and sometimes in different directions.

\section{References}

Al-Tamimi K.A.M., Obeidat S.F., 2013, Determinants of capital adequacy in commercial banks of Jordan an empirical study, International Journal of Academic Research in Economics and Management Sciences, July.

Barr R., Siems T., 1994, Predicting bank failure using DEA to quantify management quality, Federal Reserve Bank of Dallas, Financial Industry Studies Working Papers, no. 94, Accounting Research.

Beck T., Demirguc-Kunt A., Levine R., 2003, Bank Concentration and Crises, NBER Working Paper Series.

Bellotti T., Matousek R., Stewart C., 2011, Are rating agencies'assignments opaque? Evidence from international banks, Expert Systems with Applications, vol. 38, no. 4, April.

Caporale G.M., Alessi M., Di Colli S., Lopez J., 2017, Loan loss provisions and macroeconomic shocks: Some empirical evidence for Italian banks during the crisis, Finance Research Letters, 25.

Chodnicka-Jaworska P., 2016, Wplyw wskaźników finansowych na ratingi kredytowe banków z krajów strefy euro, Financial Sciences, vol. 3, Issue 28.

Chodnicka-Jaworska P., Jaworski P., 2017, Fundamental determinants of credit default risk for European and American banks, Journal of International Studies, vol. 10, no. 3.

Cleary S., Hebb G., 2016, An efficient and functional model for predicting bank distress: In and out of sample evidence, Journal of Banking \& Finance, no. 64. 
Cox R.A.K., Wang G.W.Y., 2014, Predicting the US bank failure: A discriminant analysis, Economic Analysis and Policy, no. 44.

Estrella A., Park S., Peristiani S., 2000, Capital ratios as predictors of bank failures, Federal Reserve Bank of New York Economic Policy Review.

Farooq M., Zaheer S., 2015, Are Islamic banks more resilient during financial panics?, Pac. Econ. Rev., 20(1).

Hanweck G.A., 1977, Predicting bank failure, Board of Governors of the Federal Reserve System, Research Papers in Banking and Financial Economics.

Hassan O.A.G., Barrell R., 2013, Accounting for the determinants of banks'credit ratings, Brunel University of London Economics and Finance Working Paper Series, vol. 13-02.

Hau H., Langfield S., Marques-Ibanez D., 2012, Bank ratings what determines their quality?, EBC Working Paper Series, vol. 1484, October.

Ibrahim M.H., Rizvi S.A.R., 2018, Bank lending, deposits and risk-taking in times of crisis: A panel analysis of Islamic and conventional banks, Emerging Markets Review, vol. 35.

Kasiewicz S., Rogowski W., 2006, Założenia teoretyczne i doświadczenia międzynarodowe w zakresie oceny i prognozowania zagrożenia banków upadłością, Bezpieczny Bank, no. 2(31).

Keeton W.R., William R., 1999, Does faster loan growth lead to higher loan losses? Econ. Rev. (Q II).

McDonald O., Keasey K., 2002, The Future of Retail Banking in Europe. A View from the Top, John Wiley \& Sons, Chichester .

Messai A., Jouini F., 2013, Micro and macro determinants of non-performing loans, International Journal of Economics and Financial Issues, 3.

Nieborak T., 2001, Realizacja zaleceń Komitetu Bazylejskiego ds. nadzoru bankowego dotyczacych procesu powstawania i funkcjonowania banku w polskim prawie bankowym, Ruch Prawniczy, Ekonomiczny i Socjologiczny, no. 1-2.

Olszak M., 2006, Adekwatność kapitałowa banków a podaż kredytu bankowego. Czynniki wzrostu gospodarczego w Polsce Wydawnictwo Naukowe Wydziału Zarządzania Uniwersytetu Warszawskiego, Warszawa.

Ötker-Robe I., Podpiera J., 2010, The fundamental determinants of credit default risk for European large complex financial institutions, IMF Working Paper, vol. WP/10/153.

Shen C., Huang Y., Hasan I., 2012, Asymmetric benchmarking in bank credit rating, Journal of International Financial Markets, Institutions \& Money, vol. 22.

Skała D., 2015, Saving for a rainy day? Income smoothing and procyclicality of loan-loss provisions in Central European banks, International Finance, vol. 18(1).

Thlon M., 2008, Świetność i upadek. Historia banku Lehman Brothers, Gazeta Bankowa, no. 42.

Thompson J.B., 1991, Predicting bank failures in the 1980s, Federal Reserve Bank of Cleveland, First Quarter.

Wong J., Choi K., Fong T., 2005, Determinants of the capital level in banks in Hong Kong, Hong Kong Monetary Authority Quarterly Bulletin.

Yiqiang Jin J., Kanagaretnam K., Liu Y., Liu N., 2018, Banks'loan growth, loan quality, and social capital, Journal of Behavioral and Experimental Finance.

Zaghdoudi T., 2013, Bank failure prediction with logistic regression, International Journal of Economics and Financial Issues, vol. 3, no. 2.

Żółtkowski W., 2007, Zarządzanie ryzykiem bankowym w praktyce, CeDeWu.pl, Warszawa. 